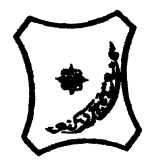

Bayero Journal of Pure and Applied Sciences, 10(2): 16 - 24

Received: April, 2017

Accepted: November, 2017

ISSN $2006-6996$

\title{
EFFECTS OF PHYSICO-CHEMICAL PARAMETERS ON THE COMPOSITION AND ABUNDANCE OF PHYTOPLANKTON IN AJIWA RESERVOIR KATSINA STATE, NORTH WESTERN NIGERIA
}

\author{
${ }^{* 1}$ Usman, L. U., ${ }^{2}$ Namadi, S. and ${ }^{3}$ Nafiu, S. A. \\ 1. Department of Biology, Umaru Musa Yar'adua University Katsina, Nigeria \\ 2. Department of Biological Sciences, Ahmadu Bello University Zaria, Nigeria \\ 3. Department of Science Laboratory Technology, School of Technology, Kano State Polytechnic \\ *Corresponding author: usman.usman@umyu.edu.ng
}

\begin{abstract}
Studies on the effects of physico-chemical parameters on the composition and abundance of phytoplanktonin Ajiwa reservoir was carried out from September, 2014 to August, 2015. Five sampling stations were chosen; the physico-chemical parameters and phytoplanktonspecies were determined using standard methods, procedures and instruments. Nineteen physicochemical parameters were determined. Some of their mean value are; Water Temperature $\left(24.05 \pm 0.38^{\circ} \mathrm{C}\right)$, Turbidity (98.0 $2.28 \mathrm{NTU})$, TDS $(70.68 \pm 2.71 \mathrm{mg} / \mathrm{I})$, Electrical Conductivity $(158.55 \pm 3.04 \mu \mathrm{S} / \mathrm{cm})$, Total Hardness (87.16 $\pm 2.37 \mathrm{mg} / \mathrm{I}), 0.0(4.10 \pm 0.13 \mathrm{mg} / \mathrm{I})$, Calcium $(40.34 \pm 1.35 \mathrm{mg} / \mathrm{I})$ and NitrateNitrogen $(1.07 \pm 0.08 \mathrm{mg} / \mathrm{l})$. The result also indicated the presence of 40 species of phytoplankton belonging to 5 major classes, viz: Chlorophyceae, Bacillariophyceae, Cyanophyceae, Dinophyceae and Euglenophyceae. The dominant phytoplankton was the Chlorophyceae (40.13\%), followed in order by Bacillariophyceae (23.94\%), Cyanophyceae (19.98\%), Euglenophyceae (8.41\%) and Dinophyceae (7.58\%). Indices of general diversity $(H)$, evenness $(E)$, dominance and relative abundance were in the following order of increasing magnitude station $5>$ station $1>$ station $4>$ station 2 and > station 3 respectively. Canonical correspondence analysis (CCA) was carried out to analyse the relationship between the physico-chemical parameters and the phytoplankton. It showed that the most important factors affecting the phytoplankton distribution are water temperature, $\mathrm{DO}, \mathrm{NO}_{3}-\mathrm{N}, \mathrm{PO}_{4}-\mathrm{P}, \mathrm{pH}, \mathrm{TDS}$ and turbidity. The fluctuation of the physicochemical parameters and phytoplankton species of the reservoir could be attributed to high influx of nutrient into the reservoir as a result of farming activities, cattle rearing, bush burning and bathing within the vicinity of the reservoir. Monitoring of human activities within the immediate catchment area of the reservoir and education on wise use of the water is recommended.
\end{abstract}

Keywords: Abundance, Composition, CCA, Physico-chemical, Phytoplankton,Reservoir.

\section{INTRODUCTION}

Freshwater ecosystems have been used for the investigation of factors controlling the abundance and distribution of aquatic organisms (Esenowo and Ugwumba, 2010). It is well established that the productivity of a reservoir depends on its ecological conditions and by monitoring the water quality; productivity can be increased to obtain maximum sustainable yield of aquatic biota (Mustapha, 2011; Usman, 2016). Maintenance of healthy aquatic environment and production of sufficient food in reservoir are primarily linked with successful reservoir culture operations. Various studies had been conducted on changes brought about by biotic and abiotic factors of river as a result of damming. However, responses of rivers and its ecosystem to damming are complex and varied as they depend on local sediment supplies, geomorphic constraint, climate, dam structure and operation (Offem and Ikpi, 2011).

Reservoir ecosystems are fragile and can undergo rapid environmental changes, often leading to significant declines in their aesthetic, recreational and aquatic ecosystem functions (Araoye, 2008). Human activities can further accelerate the rate of changes; if the causes of the changes are known, human intervention (management practices) sometimes can control or even reverse detrimental changes. Maintenance of healthy aquatic environment and production of sufficient foods in reservoir are primarily linked with successful reservoir culture operations. To keep the aquatic habitat favourable for existence of living organisms, physical and chemical factors like temperature, turbidity, $\mathrm{pH}$, odour, dissolved gases, salts nutrients must be monitored regularly, individually or synergistically, activity of living organisms is influenced by the seasonal and diurnal changes of these parameters (Akinyeye et al., 2011). Changes in the physico-chemical parameters may positively or negatively affect the biota of water bodies in a number of ways such as their survival and growth rates and these may eventually result in disappearance of some species of organisms or its reproduction (Edward and Ugwumba, 2010).

Life in aquatic environment is largely governed by physico-chemical characteristics and their stability. These characteristics have enabled phytoplankton to develop many adaptations that improve sustained productivity and regulate its metabolism (Olele and Ekelemu, 2008). Phytoplankton is a key component of the lake biota in general, because it forms the base of the pyramid of productivity (Usman, 2016). 
Physico-chemical and biotic characteristics of water are interrelated and often driven by the surrounding land uses that determine the quality of water at point sources that enter the freshwater streams (Fonge et al., 2015). Physicochemical parameters and nutrient in water play significant role in the distributional pattern and species composition of aquatic phytoplankton (Negi and Vishal, 2015). The eutrophication of water bodies accelerated by human activities creates the need for various activities to be undertaken to restore good water quality (Kozak et al., 2012).

The impoundment of river and subsequent creation of Ajiwa reservoir has assisted to provide water for drinking, irrigation and fish farming in Katsina State. However, human activities in these catchments may have cause pollution resulting from deforestation, farming activities, grazing and bush burning which enhances accelerated silting, addition of large quantities of nutrients chemicals, herbicides and organic matter in the water bodies through surface run-offs (Usman, 2016). Ezealor et al., (1999) reported that extensive human activities through agricultural practices, fertilizer application and overgrazing around the catchment areas of aquatic habitats results in marked fluctuations in the physicochemical and biological parameters of lentic ecosystems.

\section{MATERIALS AND METHODS}

Study site: Ajiwa reservoir is located at Batagarawa local government area of Katsina state, Nigeria on latitude and longitude $12^{\circ} 54^{\prime} 69^{\prime \prime}-12^{\circ} 57^{\prime} 58^{\prime \prime} \mathrm{N}$ and 7०42'53" - 7047'50" E respectively (Figure 1). The main purpose of the reservoir is irrigation and water supply to the people of Katsina, Batagarawa, Mashi, and Mani local government areas. The reservoir was impounded in 1973 and commissioned in 1975(Parkman and Haskoning, 1996).

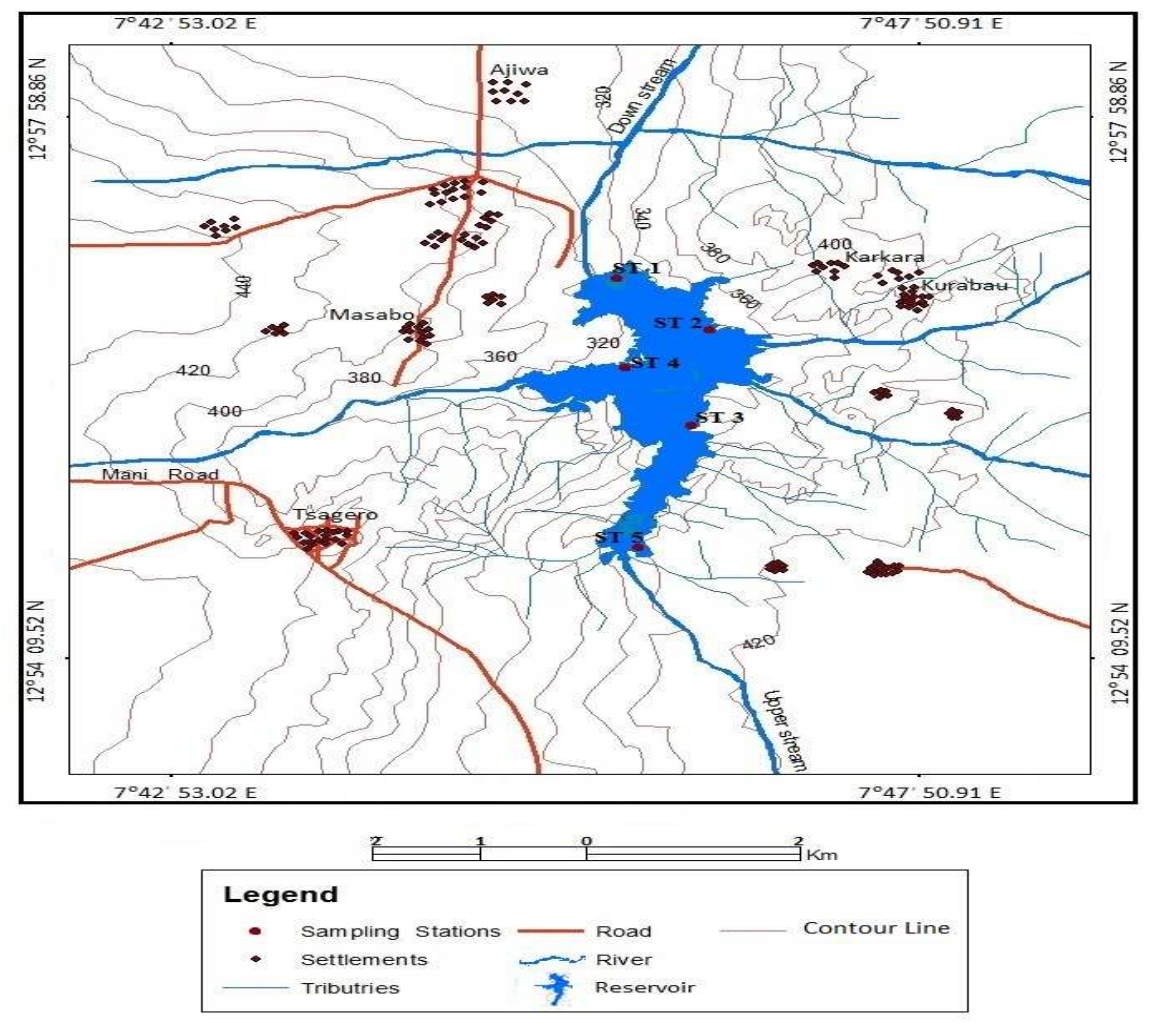

Figure 1: Map of Ajiwa Reservoir Katsina State, showing sampled stations. (Source: NASA/NOAA Spot Image 2014).

\section{Sampling Procedures}

Sampling of physicochemical and biological parameters were carried out monthly from each of the five sampling locations. Water sample and phytoplankton species were collected from September 2014 to August 2015 (12 months). Water sample were collected around 8:00am at the surface level by dipping 1 litre plastic sampling bottle sliding over the surface of the water with their mouth against the water current to permit undisturbed passage of the water into the bottle. The different physico-chemical parameters such aswater temperature, water depth, transparency, turbidity, total dissolved solids, total suspended solids,total solids, $\mathrm{pH}$, electrical conductivity, total hardness, total alkalinity, dissolved oxygen, B.O.D, chloride, calcium, magnesium, iron, nitrate-nitrogen $\left(\mathrm{NO}_{3}-\mathrm{N}\right)$ and inorganic phosphorus $\left(\mathrm{PO}_{4}-\mathrm{P}\right)$ were analysed according to APHA (1999). 


\section{Phytoplankton Analysis}

Phytoplankton were sampled with the aid of plankton net, $500 \mathrm{ml}$ of the water sample were collected from the five sampling locations, in a wide mouth plastic bottles attached to the net. $5 \mathrm{ml}$ of Lugol's iodine solution was added. After keeping it for 6 hours, the supernatant was discarded and $20 \mathrm{ml}$ concentrate was obtained. Quantitative analysis of phytoplankton was done by putting one drop of fixed sample $(0.02 \mathrm{ml})$ on the glass slide and observed usingOmax 40X-1000X Digital Lab LED Binocular Compound Microscope. The results were obtained by recording the number of organisms per $\mathrm{ml}$ following Welch (1952); Needham and Needham (1975); Jeje and Fernando (1982).

Three indices were used to obtain the estimation of species diversity, species richness and species evenness:

1. Species diversity was determined following Shannon-Wiener's Index (Ludwig and Reynolds, 1988) using the formula:

$\mathrm{H}^{\prime}=(\Sigma \mathrm{pi}$ In pi $)$

Where, $\mathrm{Pi}=\mathrm{n} / \mathrm{N} \mathrm{N}=$ No. of individual species, $\mathrm{N}=$ total density of all organisms.

2. Species dominance was calculated using BergerParker's Index (Berger and Parker, 1970) formula:

$\mathrm{D}=\mathrm{Nmax} / \mathrm{N}$

Where Nmax = density of most dominant species, $\mathrm{N}$ $=$ density of all the species.

3. Evenness was calculated using the formula:

$\mathrm{E} 1=\mathrm{H} 1 /$ In S (Pielou, 1975)

Where, $\mathrm{H} 1$ = species diversity; $\mathrm{S}=$ species richness.

Ordination Analysis of Phytoplankton Community

The SPSS16 Software Design was used for performing multivariate analysis of ecological data by canonical correspondence analysis (CCA) conducted to detect patterns of distribution of various phytoplankton groups related to physical and chemical parameters. The results contain the environmental variables plotted as arrows emanating from the centre of the graph along with points for the samples and phytoplanktongroups. The arrows representing the environmental variables indicate the direction of maximum change of that variable across the diagram. The position of the taxa (species) points indicates the environmental preference of the species.

\section{RESULTS AND DISCUSSIONS}

Variations in the physico-chemical parameters of Ajiwa reservoir is given in figure 2 and table 1.The reservoir is influenced by a wide array of physicochemical factors. Fluctuations of these factors affect the phytoplankton of the reservoir. Water temperature of Ajiwa reservoir fluctuated within months $\left(16.5 \pm 0.52^{\circ} \mathrm{C}\right.$ to $\left.28.0 \pm 0.30^{\circ} \mathrm{C}\right)$ in all the five sampling station. The lowest mean water temperature $\left(16.5 \pm 0.52^{\circ} \mathrm{C}\right)$ recorded in the reservoir was in the dry season, this could be attributed to seasonal changes in air temperatures associated with the cool dry North-East winds. This observation is supported by the findings of Adakole et al. (2000), which attributed variations in water temperature in the dry season to the effect of harmattan. High water temperature stress aquatic ecosystem by reducing the ability of water to hold essential dissolved gases like oxygen which cause fish and other invertebrate mortality (Kumar and Bahadur, 2009). Ajiwa reservoir showed high mean water temperature $\left(28.0 \pm 0.30^{\circ} \mathrm{C}\right)$ during the wet season, this may be due to characteristic of the tropical weather. This corresponds with the findings of Indabawa (2009) and Kolo et al. (2010), in their studies of the ecology of fresh water phytoplankton of river Hadejia Jigawa State, and in Shiroro Lake respectively.

Table 1: Mean Seasonal Variation of Physico-chemical Parameters in Ajiwa Reservoir Katsina, Nigeria

\begin{tabular}{|c|c|c|c|c|c|}
\hline Physicochemical Parameters & $\begin{array}{l}\text { Wet } \\
\text { Season }\end{array}$ & $\begin{array}{l}\text { Dry } \\
\text { Season }\end{array}$ & $\begin{array}{l}\text { Mean } \\
\text { Value }\end{array}$ & $\begin{array}{l}\text { WHO } \\
\text { Standard (2011) }\end{array}$ & $\begin{array}{l}\text { USEPA } \\
\text { Standard } \\
(2002)\end{array}$ \\
\hline Water Temp. $\left({ }^{\circ} \mathrm{C}\right)$ & $25.85 \pm 0.30$ & $20.25 \pm 0.52$ & $24.05 \pm 0.38$ & - & - \\
\hline Water Depth (m) & $4.43 \pm 0.33$ & $0.24 \pm 0.27$ & $3.84 \pm 0.23$ & - & - \\
\hline Transparency (cm) & $35.10 \pm 1.80$ & $29.57 \pm 0.94$ & $32.33 \pm 1.07$ & 06 & 15 \\
\hline Turbidity (NTU) & $106.57 \pm 3.65$ & $80.03 \pm 1.77$ & $98.30 \pm 2.28$ & 06 & $0-5$ \\
\hline TDS(mg/l) & $51.09 \pm 3.61$ & $86.26 \pm 3.24$ & $70.68 \pm 2.71$ & 500 & 500 \\
\hline TSS (mg/l) & $29.81 \pm 1.56$ & 14. $21 \pm 0.75$ & $17.01 \pm 0.93$ & - & - \\
\hline Total Solids (mg/l) & $85.72 \pm 2.59$ & 103. $03 \pm 2.75$ & $87.37 \pm 2.07$ & 500 & 500 \\
\hline $\mathrm{pH}$ & 7. $34 \pm 0.12$ & $6.67 \pm 0.08$ & $7.01 \pm 0.09$ & 6.5 & $6.5-8.5$ \\
\hline $\mathrm{EC}(\mu \mathrm{S} / \mathrm{cm})$ & $147.55 \pm 4.80$ & $169.55 \pm 2.48$ & $158.55 \pm 3.04$ & - & - \\
\hline Total Hardness (mg/l) & $81.21 \pm 2.65$ & $93.10 \pm 3.67$ & $87.16 \pm 2.37$ & - & - \\
\hline DO & $4.50 \pm 0.20$ & $2.69 \pm 0.12$ & $4.10 \pm 0.13$ & - & - \\
\hline BOD & $1.01 \pm 0.08$ & $1.74 \pm 0.07$ & $1.47 \pm 0.06$ & - & - \\
\hline Calcium & $31.47 \pm 1.89$ & $49.21 \pm 1.67$ & $40.34 \pm 1.35$ & 75 & 65 \\
\hline $\mathrm{NO}_{3}-\mathrm{N}(\mathrm{mg} / \mathrm{l})$ & $1.41 \pm 0.11$ & $0.73 \pm 0.05$ & $1.07 \pm 0.08$ & 50 & 10 \\
\hline $\mathrm{PO}_{4}-\mathrm{P}(\mathrm{mg} / \mathrm{l})$ & $0.67 \pm 0.05$ & $0.40 \pm 0.03$ & $0.53 \pm 0.03$ & - & 0.7 \\
\hline Chloride (mg/l) & $47.37 \pm 2.12$ & $68.15 \pm 2.21$ & $52.26 \pm 1.65$ & 200 & 250 \\
\hline Total Alkalinity $\left(\mathrm{mgCaCO}_{3} / \mathrm{l}\right)$ & $33.11 \pm 1.35$ & $51.85 \pm 1.43$ & $47.48 \pm 1.13$ & - & - \\
\hline Magnesium (mg/l) & $1.68 \pm 0.18$ & $2.73 \pm 0.15$ & $2.21 \pm 0.14$ & 50 & 50 \\
\hline $\operatorname{Iron}(\mathrm{mg} / \mathrm{l})$ & $0.28 \pm 0.15$ & $0.72 \pm 0.02$ & $0.50 \pm 0.02$ & 0.1 & 0.3 \\
\hline
\end{tabular}


The mean water depth of Ajiwa reservoir for the wet and dry seasons during the study period were $4.43 \pm 0.33 \mathrm{~m}$ and $0.24 \pm 0.27 \mathrm{~m}$ respectively as shown in figure 2. The decrease in water depth especially during the dry season was probably caused by high evapo-transpiration and cessation of rainfall. Ibrahim et al. (2009) made similar observation of water depth fluctuation with season in Kwantagora reservoir. The depth of the reservoir decreases light intensity Tisser et al. (2008). Light penetration depends on the available intensity of the incident light, which varies with geographical location of a reservoir (Usman, 2016).

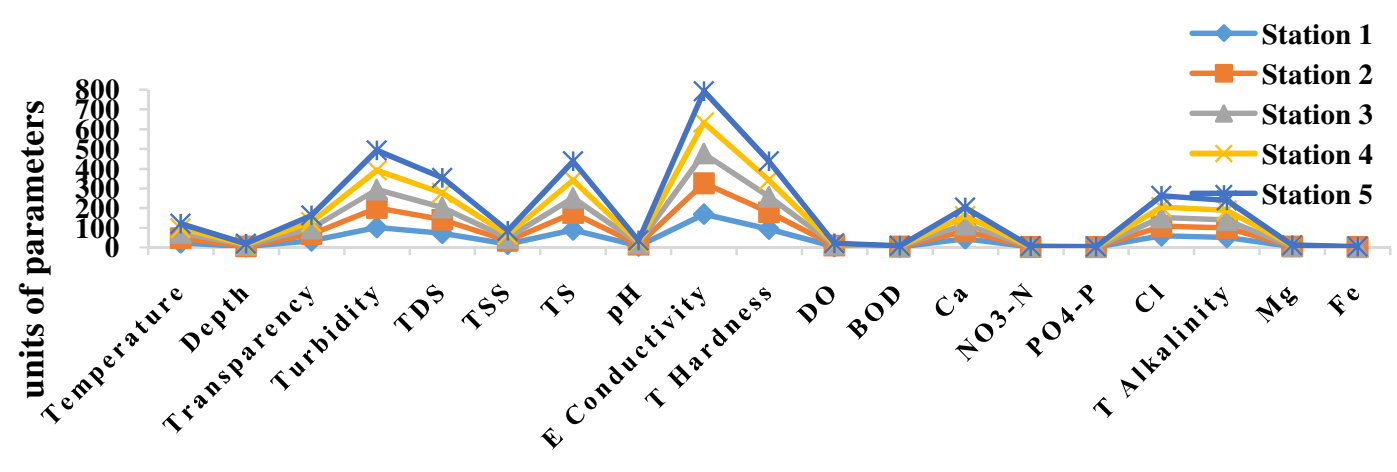

Physicochemical Parameters

Figure 2: Mean Variation of Physicochemical Parameters Among Sampled Stations in Ajiwa Reservoir Katsina State.

The high dry season electrical conductivity value $(169.55 \pm 2.48 \mu \mathrm{S} / \mathrm{cm})$ may be due to the higher rate of evaporation that reduces the water level and increase in nutrients due to run off from inorganic fertilizer from irrigation farm lands. Decrease in conductivity values $(147.55 \pm 4.80 \mu \mathrm{S} / \mathrm{cm})$ during the rainy season might be due to increase in rainwater which cause dilution of the dissolved solids in the reservoir. This was similar to the observation of Gadzama and Mondo (2011). Increases in total dissolved organic matter results in increase in electrical conductivity. This agrees with observation made by Adakole (2000) in his Limnological study of river Kubani, Zaria.

Turbidity of water is affected by the amount of the suspended solids in it, hence restricts the light penetration and indirectly affect the phytoplankton growth (Usman, 2016). High turbidity observed in Ajiwa reservoir (106.57 $\pm 3.65 \mathrm{NTU})$ during the rainy season could be due to increase in surface run-off, which cause re-suspension of dissolved materials. This supports the observation of Mustapha (2011) that attributed high turbidity to increase in tributary input of suspended materials and surface run-off. Increase in total dissolved solids might have resulted to the increase in turbidity. This agrees with the observation of Adakole (2000) who reported that re-suspension of dissolved solids increases turbidity. Lowest turbidity observed during the dry season could be as a result of prevailing condition of less-surface run-off. This correspond with the findings of Ladipo et al. (2012).

Ajiwa reservoir has higher value of TDS during the dry season than wet season; $86.26 \pm 3.24 \mathrm{mg} / \mathrm{l}$ and $51.09 \pm 3.61 \mathrm{mg} / \mathrm{l}$ respectively as shown in figure 2 . This could be due to decaying of vegetation and higher rate of evaporation. Similar observation was made by Atobatele and Ugwumba (2008). The total dissolved solids negative correlation with dissolved oxygen and biochemical oxygen demand may be due to inflow of substance during the rainy season and settling effect of the substance in dry season. This agree with the findings of Araoye (2008).

A pH range of 6.0 to 9.0 appears to provide protection for the life of fresh water fish and bottom dwelling invertebrates (U.S.E.P.A, 2005). Mean pH of Ajiwa reservoir was within $6.67 \pm 0.08$ to $7.34 \pm 0.12$ (figure 2 ) throughout the study period making the water of the reservoir to be circum-neutral. This was similar with the results of Ibrahim et al. (2009) which reported that $\mathrm{pH}$ was nearly neutral throughout both seasons in Kontagora reservoir. The $(7.34 \pm 0.12)$ of $\mathrm{pH}$ during the dry season may be due to decomposition of living organisms in the water coupled with the reduction in the water level during the dry season. This observation agrees with that of Mustapha (2011). The little decrease in $(6.67 \pm 0.08)$ $\mathrm{pH}$ during the rainy season was probably due to the stirring effect of the incoming flood from the rivers that converged towards the lake resulting in the mixing of the poorly alkaline or acidic bottom water with alkaline surface water to reduce $\mathrm{pH}$ in the reservoir.

Oxygen gets into water by diffusion from the surrounding air, by aeration (rapid movement) and as a waste product of photosynthesis (Kumar and Bahadur, 2009). The values for dissolved oxygen concentration of Ajiwa reservoir in all the five sampling stations fall within the mean range of $2.69 \pm 0.12 \mathrm{mg} / \mathrm{l}$ to $4.50 \pm 0.20 \mathrm{mg} / \mathrm{l}$ and the lowest concentration during dry season could be attributed to the peak time of biochemical oxygen demand due to bacteria and other decomposers uptake. 
This correspond with the findings of Balogun, et al. (2005). The higher the temperature the lower the dissolved oxygen and the lower the temperature the higher dissolved oxygen (Adakoleet al., 2012). Alkalinity was varied from $33.11 \mathrm{mg} / \mathrm{l}$ to $51.85 \mathrm{mg} / \mathrm{l}$ as shown in figure 2 . Decline in conductivity values in wet season could be related to increase in phytoplankton and macrophyte population leading to increase in the uptake of nutrients. Hardness concentration in present study ranged between $81.21 \mathrm{mg} / \mathrm{l}$ to $93.10 \mathrm{mg} / \mathrm{l}$. High values of total hardness were recorded during dry season can be related to inflowing sewage and high anthropogenic activities in and around the reservoir.

Nandan and Aher (2005) reported the algal genera, Euglena, Oscillatoria, Scenedesmus, Navicula, Nitzschia and Microcystis are the species found in organically polluted waters. Similar genera were recorded in the present investigation thereby showing that Ajiwa reservoir is organically polluted (Table 2 and Figure 3). Phytoplankton communities in general can be used as indicators of pollution for assessing the water quality (Usman, 2016). The algae like Microcystisaeruginosa was used as the best single indicator of pollution and it was associated with the highest degree of civic pollution (Nandan and Aher, 2005). In the present study, Microcystis was also recorded in the selected site table 2 . The occurrence of Oscillatoria in the present study indicates pollutants of biological origin which agreed with the observations of Altaf and Saltanat (2014) and Gadag et al. (2005). It is reported that excessive growth of certainalgal genera, viz., Scenedesmus, Anabaena, Oscillatoria and Melosira indicate nutrient enrichment of aquatic bodies (Kumar, 1990; Zargar and Ghosh, 2006).The present study in Ajiwa reservoir also support the findings. Studies show that the dominant phytoplankton and their seasonality are highly variable in different water bodies according to their nutrient status, age, morphometric and other locational factors (Gopal and Zutshi, 1998).

Table 2:Distribution and Abundance of Phytoplankton Population in Ajiwa Reservoir KatsinaState, Nigeria (individual/L)

\begin{tabular}{|c|c|c|c|c|c|}
\hline Taxon & Station 1 & Station 2 & Station 3 & Station 4 & Station 5 \\
\hline \multicolumn{6}{|l|}{ Chlorophyceae } \\
\hline Spirogyra sp & 65 & 46 & 16 & 53 & 87 \\
\hline Oedogonium sp & 9 & 2 & 0 & 0 & 0 \\
\hline Chlamydomonas sp & 58 & 16 & 12 & 24 & 66 \\
\hline Volvox sp & 16 & 23 & 0 & 12 & 10 \\
\hline Staurastrum tetracerum & 2 & 16 & 2 & 0 & 24 \\
\hline Scenedesmus dimorphus & 0 & 0 & 0 & 2 & 8 \\
\hline Characium acuminatum & 4 & 12 & 2 & 0 & 2 \\
\hline Ulothrix sp. & 0 & 0 & 4 & 11 & 17 \\
\hline Oocystis sp. & 5 & 2 & 0 & 8 & 2 \\
\hline Closterium venus & 88 & 64 & 20 & 46 & 92 \\
\hline Pediastrum simplex & 2 & 0 & 0 & 2 & 6 \\
\hline Dictyochloris sp. & 6 & 2 & 2 & 0 & 0 \\
\hline Tetraedron sp. & 4 & $\overline{0}$ & 0 & 0 & 2 \\
\hline Euastrum sp. & 0 & 0 & 4 & 0 & 4 \\
\hline Zygnema fanicum & 30 & 4 & 2 & 18 & 42 \\
\hline \multicolumn{6}{|l|}{ Cyanophyceae } \\
\hline Anabaena circinalis & 46 & 37 & 14 & 34 & 89 \\
\hline Microcystis sp & 12 & 0 & 2 & 6 & 11 \\
\hline Phormidium tenue & 0 & 0 & 0 & 0 & 2 \\
\hline Oscillatoria Formosa & 64 & 22 & 11 & 34 & 65 \\
\hline Calothrix sp. & 0 & 0 & 0 & 2 & 0 \\
\hline Nostoc sp. & 48 & 12 & 4 & 2 & 6 \\
\hline Gomphosphaeria sp. & 0 & 0 & 0 & 0 & 2 \\
\hline Chroococcus sp. & 0 & 6 & 2 & 2 & 2 \\
\hline \multicolumn{6}{|l|}{ Bacillariophyceae } \\
\hline Diatoma sp. & 14 & 10 & 22 & 28 & 34 \\
\hline Melosira listaus & 0 & 2 & 0 & 6 & 17 \\
\hline Navicula placentula & 84 & 30 & 12 & 42 & 66 \\
\hline Fragilaria sp & 0 & 2 & 0 & 0 & 2 \\
\hline Tabellaria fevar & 2 & 0 & 4 & 2 & 6 \\
\hline Pinmularia major & 14 & 2 & 10 & 6 & 18 \\
\hline Cyclotella operculata & 38 & 24 & 2 & 23 & 47 \\
\hline Cymbella sp & 19 & 6 & 4 & 11 & 0 \\
\hline Gyrosigma atternuatum & 0 & 2 & 0 & 0 & 8 \\
\hline Epithermia zebra & 4 & 2 & 4 & 0 & 0 \\
\hline Diatomella sp & 2 & 0 & 0 & 0 & 0 \\
\hline Anomoneis sp & 2 & 2 & 2 & 4 & 2 \\
\hline \multicolumn{6}{|l|}{ Dinophyceae } \\
\hline Spirotaenia sp & 10 & 6 & 0 & 4 & 8 \\
\hline Peridinium sp & 22 & 4 & 4 & 8 & 2 \\
\hline & 49 & 18 & 12 & 21 & 36 \\
\hline \multicolumn{6}{|l|}{ Euglenophyceae } \\
\hline Euglena sp & 64 & 42 & 18 & 31 & 53 \\
\hline Phacus sp & 8 & 4 & 2 & 4 & 0 \\
\hline
\end{tabular}




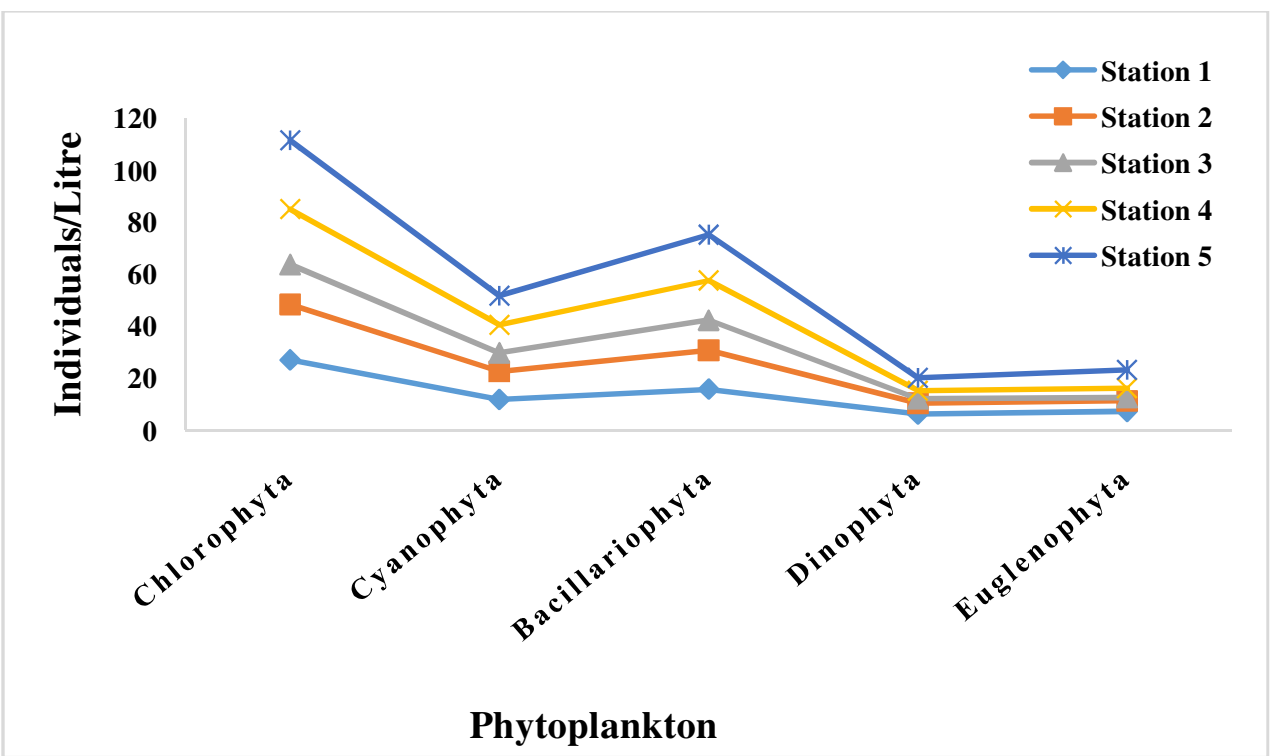

Figure 3: Mean Variation of Some Phytoplankton among Sampled Stations in Ajiwa Reservoir Katsina State.

The indices of general diversity $(H)$, evenness $(E)$ and dominance calculated for the five stations are presented in Table 3.Species diversity which is a function of species richness and evenness with which the individuals are distributed in these species (Margalef, 1958).Although diversity was higher at station 1 , station 4 and station 5 . Evenness, dominance and relative abundance were higher in the following order of increasing magnitude station $5>$ station $1>$ station $4>$ station 2 and $>$ station 3 respectively. Highest values of Shannon-Wiener Index were recorded for Euglenophyta (1.53, Table 3) and lowest values were recorded for Cyanophyta (1.46, Table 3). Shannon-Weiner diversity index proposed as diversity index greater than ( $>4$ ) is clean water; between 3-4 is mildly polluted water and less than 2 $(<2)$ is heavily polluted water (Shekhar et al., 2008). Since, the Shannon-Weiner diversity index in the present study ranged between $1.46-1.53$ in the selected water body, therefore, this water body oscillates between moderately polluted to highly pollute. Maximum evenness values were recorded for Euglenophyta (0.93, Table 3) and evenly minimum values distributed for Cyanophyta, (0.86). The present results indicate consistently higher phytoplankton evenness with broadly identical values (Table 3 ). This reflects equitable abundance of various species throughout the study period.
Canonical Correspondence Analysis (CCA)

Ordination of CCA, the group environmental bi-plot (Figure 4) shows the relations of the groups and environmental variables with the ordination axis. In the graph, environmental factors are indicated by the line, length of line represents the degree of relationship between sample plots, the distribution of biota and environmental factors.

The length of the arrow indicates the relative importance of the environmental variable in determining the axis. The positions of the group's centres (points) along the ordination axis represent their respective optima along the environmental gradient. The group environmental correlation with axis correlated well with D.O, water temperature, alkalinity, transparency, TDS, chlorides and $\mathrm{NO}_{3}-\mathrm{N}$. The euglenophyta has the highest values on this axis. Group with lowest correlation with this axis was bacillariophyta. In addition, the analysis make vertical lines connecting a particular group with the line of environmental factors closer to the connecting point near the line of environmental factor showing strong positive correlation.

Further, the most important factors affecting phytoplankton distributions are water temperature, $\mathrm{NO}_{3}-\mathrm{N}$, turbidity, TDS, alkalinity and dissolved oxygen (Figure 4). However, conductivity, magnesium, iron and hardness has lesser influence on the distribution of phytoplankton groups. 
Bajopas Volume 10 Number 2 December, 2017

Table 3: Composition and Abundance of Phytoplankton in Ajiwa Reservoir Katsina

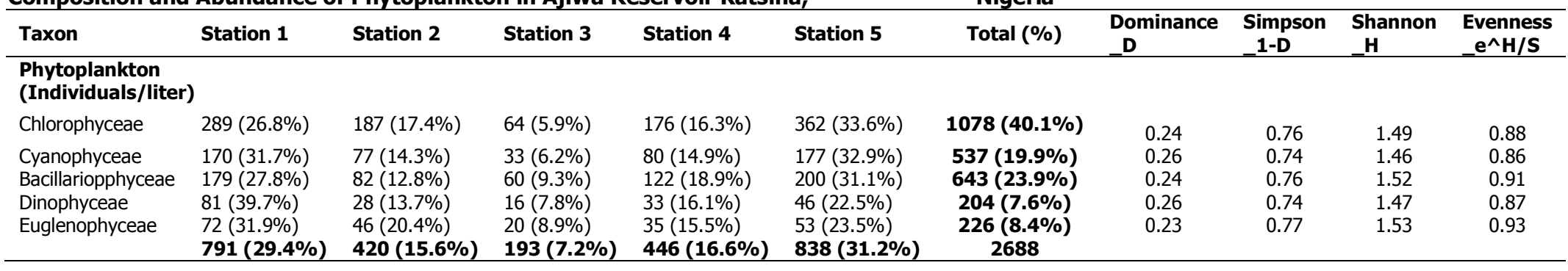

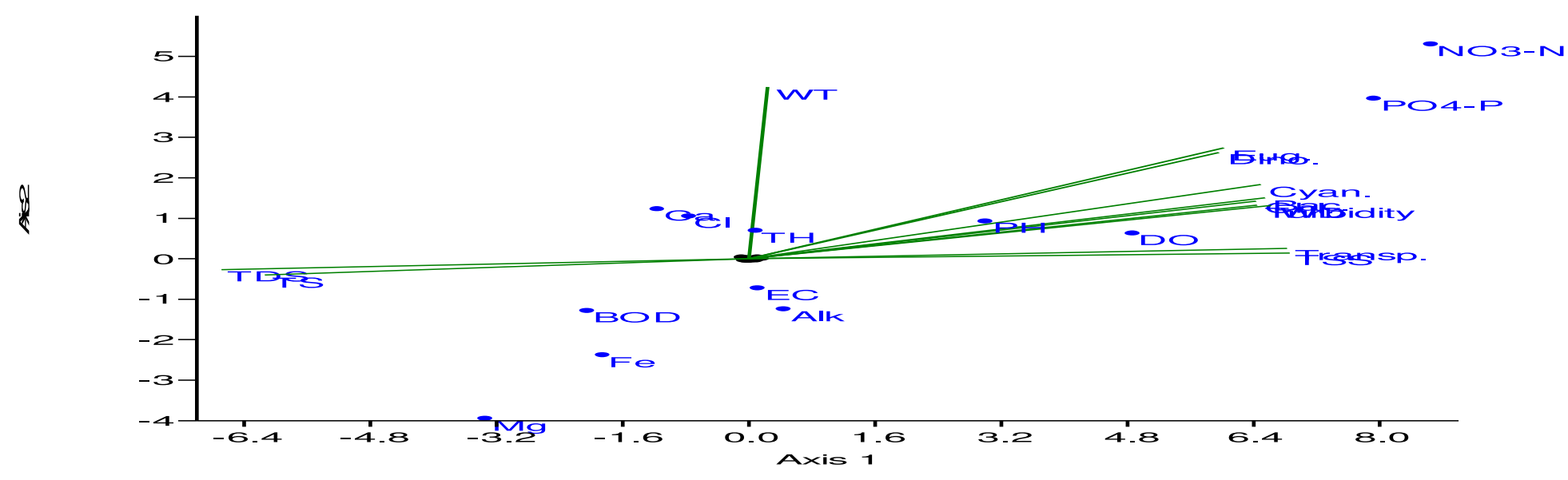

Figure 4. Canonical Correspondent Analysis (CCA) of Phytoplankton Community in Ajiwa Reservoir, Katsina State.

Key:

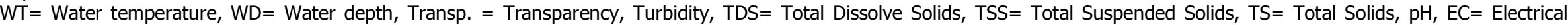

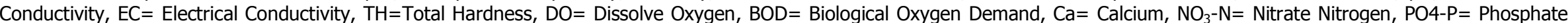
Phosphorous, $\mathrm{Cl}=$ Calcium, Alk= Alkaliniy, $\mathrm{Mg}=$ Magnesium, $\mathrm{Fe}=$ Iron, Chlorophyta, Cyanophyta, Bacillariophyta, Dinophyta and Euglenophyta 


\section{CONCLUSION}

The study revealed that the water quality parameters such aswater temperature, $\mathrm{DO}, \mathrm{NO}_{3}-\mathrm{N}, \mathrm{PO}_{4}-\mathrm{P}, \mathrm{pH}$, TDS and turbidity play a very important role in altering the phytoplankton distribution. The human anthropogenic are the main causative agents in the increase of the nutrients inAjiwa Reservoir.

Estimates of phytoplankton species composition in this study exhibited a pattern that indicates the effects of domestic activities in the reservoir. Thus

\section{REFERENCES}

Adakole, J. A. (2000). The Effects of Domestic, Agricultural and Industrial Effluents on the Water Quality and Phytoplankton of Bindere Streams, Zaria-Nigeria. (Unpublished PhD Thesis) Department of Biological Sciences, A.B.U. Zaria, Nigeria. Pp. 32-46

Adakole, J. A., Abolude, D.S. and Balarabe, M.L. (2012). Assessment of Water Quality of a Man-Made Lake in Zaria, Nigeria. Proceedings of Taal: The 12th World Lake Conference: 1373-1382.

Akinyeye, A.J., Komolafe, J.I. and Okorie, T.G. (2011). Limnological Assessment of Effluents on Invertebrates from Alaro River in Oluyole industrial area of Ibadan, Oyo State, Nigeria. Agriculture and Biology Journal of North America,2(7): 53- 58. Retrieved from http://www.scihub.org/ABJNA

Altaf, H. G. and Saltanat, P. (2014) Effect of physicochemical conditions on the structure and composition of the phytoplankton community in Wular Lake at Lankrishipora, Kashmir. International Journal of Biodiversity and Conservation. 6(1), pp. 71-84.

APHA (American Public Health Association) (1999). Standard Methods forExamination of Water and Waste Water. American Public Health Association, New York, U. S.A. 1-8pp.

Araoye, P.A. (2008). Physical factors and their Influence on Fish Species Composition in Asa Lake, Ilorin, Nigeria. International Journal of Tropical Biology,57 (1-2): 167- 175.

Atobatele, O.E. and Ugwumba, O.A. (2008). Seasonal Variation in the Physico-chemistry of a Small Tropical Reservoir (Aiba Reservoir, Iwo, Osun, Nigeria). African Journal ofBiotechnology,7(12):62-171. Retrieved from http://www.academicjournals.org/AJB on $23 / 12 / 2016$

Balogun, J.K., Balarabe, M.L. and. Igberaese, P.M. (2005). Some Aspects of the Limnology of Makwaye (Ahmadu Bello University Farm) Lake, Samaru, Zaria. Academic Journal, 23(12):850-860.

Berger, W. H.and Parker, F. L. (1970). Diversity of Planktonic foraminifera in deep sea sediments. Science, 168:1345-47.

Edward, J.B. and Ugwumba, A.A.A. (2010). PhysicoChemical Parameters and Plankton Community of Egbe Reservoir, Ekiti State, Nigeria. Research Journal of Biological Sciences 5 (5): 356-367. tolerant groups such as cyanophyceae, and euglenophyceae that survive under higher organic conditions indicate some level of contamination in the reservoir.

From CCA, it was concluded that the most important factors affecting the phytoplankton distribution are water temperature, D.O, water depth, $\mathrm{NO}_{3}-\mathrm{N}, \mathrm{PO}_{4}-\mathrm{P}$, $\mathrm{pH}, \mathrm{BOD}, \mathrm{TDS}$ and turbidity. However, conductivity, iron, magnesium and hardness has lesser influence on the distribution of the phytoplankton.

Esenowo, I.K. and Ugwunba, A.A.A. (2010). Composition and abundance of Macrobenthes in Majidun River Ikorodu Lagos State. Nigerian Research Journal of Biological Sciences,5(8): 556-560.

Ezealor, A.U., Gbem, T.T., Kwande, W.S., Auta, J. and Bako, S.P. (1999). Sedimentation: A threat to man-made reservoirs in the savanna ( $A$ case study of Kubani Reservoir, Zaria, Nigeria). A paper presented at the International Seminar on the Performance of Large and small-scale Irrigation Schemes in Africa, Abuja, Nigeria, pp18-31.

Fonge, B. A., Tabot, P. T., Mange, C. A. and Mumbang, C. (2015).Phytoplankton community structure and physico-chemical characteristics of streams flowing through an agro- plantation complex in Tiko, Cameroon.Journal of Ecology and the Natural Environment, 7 :( 5):170-179.

Gadag, S.S., Kodashetter, M.S., Birasal, N.R. and Sambrani, M.I (2005). Of the microphytes and macrophytes in and around Heggeri lake (Haveri district). Proc. State level UGC sponsored seminar on biodiversity and its conservation held at KLE society's Gudleppa Hallikeri College, Haveri, 28-29th July 2005. p. 91.

Gadzama, I. M. K. and Mondo, N. J. (2011). Assessment of the influence of limnological factors on the malacofauna of two major man-made lake in Zaria, Nigeria. International Journal of Biology and chemical Science, 5(5):1898-1906.

Gopal, B. and Zutshi D.P (1998). Fifty years of hydrobiological research in India. Hydrobiologia, 384(1) :267- 290.

Ibrahim, B.U., Auta, J. and Balogun, J.K. (2009). An Assessment of the Physico-chemical Parameters of Kontagora Reservoir, Niger state, Nigeria. Bayero Journal of Pure and Applied Sciences, 2(1): 64 - 69

Indabawa, I. I. (2009). Studies on Limnological Parameters and Phytoplankton Dynamics of Nguru Lake, Yobe State, Nigeria. Bioscience Research Communications, 21(4), 183- 188.

Jeje, C.Y and C.K Fernando (1982) A Practical Guide to the Identification of Nigeria Zooplankton Kainji Lake Institute.

Kolo, R.J. Ojutiku, R.O and Musulmi, D.T. (2010). Plankton Communities of Tagwai dam Minna, Nigeria. Continental Journal of Fisheries and Aquatic Science 4:14-20 
Bajopas Volume 10 Number 2 December, 2017

Kozak, A. Gołdyn, R. Katarzyna k. and Zimmer, M (2012). Water quality and phytoplankton of the recreational used Lake Sławskie. Polish Journal of Natural Sciences, 27(4): 419-431.

Kumar, A. and Bahadur, Y. (2009). Physico-Chemical Studies on the Pollution Potential of River Kosi at Rampur India. World Journal of Agricultural Sciences, 5(1): 1-4.

Kumar, H.D (1990). Introductory Phycology. Pub. Affiliated East West Press Pvt. Ltd.

Ladipo, M. K., Ajibola, V.O. and Oniye, S.J. (2012). Application of multivariate statistical method to assessment of water quality in selected locations of Lagos lagoon, Nigeria Environmental Research Journal, 6(3): 141150.

Ludwig, J.A, Reynolds, J.F (1988). Statistical Ecology: A primer on methods and computing. John Wiley and Sons, New York.

Margalef, R. (1958). Information theory in ecologyGen.Sys. 3: 36-71.Transl. R. Acad. Ciene. Artes. Barc. 32: 373-449.1957.

Mustapha, M.K. (2011). Perspectives in the Limnology of Shallow Tropical African Reservoirs in Relation to Their Fish and Fisheries. Journal of Transdisciplinary Environmental Studies,10(1):16-23.

Nandan, S.N. and Aher, N.H. (2005). Algal community used for assessment of water quality of Haranbaree dam and Mosam river of Maharashtra. J. Enviro. Biol., 26(1):223-227.

Needham, J.G. and Needham, P.R. (1975). A Guide to the Study of Freshwater Biology $4^{\text {th }}$ edition, Holden - Day Inc., San Francisco, 1683 pp. NRC (1989). National Research Council Recommended dietary allowances, 10th ed. Washington, DC, National Academy Press. P 89.

Negi, R. K and Vishal R. (2015). Assessment of Phytoplankton Diversity in Relation to Abiotic Factors of Nainital Lake of Kumaon Himalayas of Uttarakhand State, India. Asian Journal of Scientific Research, 8(1): 157-164.
Offem, B. O. and Ikpi, G. U. (2011). Water Quality and Environmental Impact Assessment of a Tropical Waterfall System, Environment and Natural Resources Research,11(1): 45- 52.

Olele, N.F. and Ekelemu, J.K. (2008). Physicochemical and Phytoplankton Study of Onah Lake, Asaba, Nigeria. African Journal of General Agriculture, 4(3): 25 - 32.

Parkman, B. and Haskoning, M. (1996). Reconstruction of Ajiwa Reservoir Katsina, Katsina state. Nigeria. P 1-23.

Pielou E.C. (1975). Ecological Diversity. New York: Wiley. [A general book on ecological diversity. Entropy-based diversity measures. Models (for the distribution of species)]

Shekhar S.T.R, Kiran B.B, Puttaiah T., Shivraj Y., Mahadevan K.M. (2008). Phytoplankton as index of water quality with reference to industrial pollution. Journal of Environmental Biology, 29(2):233-236.

Tiseer, F.A., Tanimu, Y. and Chia, A.M. (2008), Seasonal Occurrence of Algae and Physicochemical Parameters of Samaru Stream, Zaria, Nigeria. Asian Journal ofEarth Sciences, 1(1): 31-37.

U.S.E.P.A. (2005). United State Environmental Protection Agency, Report to Congress Nonpoint Source Pollution in the US Gov't Print Office Washington D.C 35Pp.

Usman, L. U. (2016). Some Limnological and Biological Aspects of Ajiwa Reservoir, Katsina State, Nigeria. (M.Sc. Dissertation). Department of Biological Sciences, Ahmadu Bello University, Zaria. Pp 112-118.

Welch, P. S. (1952) Limnology, $2^{\text {nd }}$ edition. McGrawHill Book co., New York. Pp 538

Zargar, S. and Ghosh, T.K. (2006). Influence of cooling water discharges from Kaiga nuclear power plant on selected indices applied to plankton population of Kadra Reservoir. Journal of Environmental Biology, 27(1):91198. 